\title{
JEPARA WOOD CARVING AND THE CULTURAL INFLUENCES OF THE NUSANTARA MARITIME SPICE ROUTE
}

\author{
Freddy Chrisswantra \\ (Email: freddy.chrisswantra@art.maranatha.edu) \\ Interior Design Study Program \\ Art and Design Faculty \\ Maranatha Christian University \\ Jl. Prof. drg. Surya Sumantri, M.P.H.no.65, Bandung, West Java, Indonesia
}

\begin{abstract}
ABSTRAK
Meningkatnya kebutuhan rempah-rempah di dunia memicu berbagai ekspedisi untuk mencari sumber rempah-rempah di dunia. Kegiatan pencarian asal usul rempah-rempah ini melahirkan sistem dan jalur perdagangan internasional. Munculnya jalur rempah-rempah ini mengakibatkan munculnya pelabuhanpelabuhan perdagangan yang menjadi cikal bakal munculnya kerajaan-kerajaan baru. Jepara merupakan salah satu kerajaan yang muncul karena memiliki pelabuhan di kawasan yang strategis di jalur perdagangan rempah-rempah. Hiruk pikuk aktivitas perdagangan di Jepara juga mempengaruhi kehidupan sosial masyarakat Jepara yang telah lama dikenal dengan keterampilan mengukir. Pedagang yang datang dari berbagai pelosok negeri dan luar negeri membuka peluang terjadinya pencampuran budaya, yang berdampak pada budaya, keahlian, dan penerapan corak dalam seni ukir kayu Jepara. Dalam tulisan ini, peneliti mencoba memitigasi perkembangan dan pengaruh akulturasi yang dibawa oleh pedagang asing dengan pendekatan historiografis untuk memudahkan membaca dampak jalur rempah bahari terhadap perkembangan seni ukir di Jepara. Hasil dari penelitian ini memperlihatkan aplikasi berbagai motif ukiran seni pahat kayu di Jepara pada berbagai artefak sebagai dampak pengaruh dari budaya yang bercampur pada masa itu
\end{abstract}

Kata Kunci: jalur rempah; akulturasi; budaya; seni pahat; jepara

\section{ABSTRACT}

The increasing need for spices in the world triggers various expeditions to find sources of spices in the world. The activity of searching for the origin of these spices gave birth to international trade systems and routes. The emergence of this spice route resulted in the emergence of trading ports which became the forerunner to the emergence of new kingdoms. Jepara was one of the kingdoms that emerged because it had a port in a strategic area on the spice trade route. The hustle and bustle of trading activities in Jepara also affects the social life of the Jepara people who have long been known for their carving skills. Traders who come from various parts of the country and abroad open up opportunities for cultural mixing, which has an impact on culture, expertise, and the application of patterns in the art of Jepara wood carving. In this paper, the researcher tries to mitigate the development and influence of acculturation brought by foreign traders with a historiography method to make it easier to read the impact of the maritime spice route on the development of carving in Jepara. The results of this study shows the application of various wood carving motifs to various artifacts as a result of the influence of the mixed culture in Jepara at that time.

Keywords: maritime spice routes; acculturation; culture; carving art; jepara 


\section{INTRODUCTION}

The Maritime Spice Route describes a sea voyage expedition that aims to find the source of various spice producers in the world, including the archipelago. Indonesia is called the archipelago because it consists of many islands with vast water areas. Therefore, maritime activities in the archipelago are not new because they have been carried out since prehistoric times (Poelinggomang, 2001). In the 17th and 18th centuries, over time, Indonesia's territorial waters became a strategic area for producing spices such as nutmeg, cloves, and cinnamon in Southeast Asia. This has triggered the emergence of various major shipping, trade, and port networks in Indonesia (Wibisono, 2004).

Around the 15th century, the trading ports around the archipelago trade shipping lanes were still small. However, over time, these trading ports grew and had complete facilities so that they deserved to be called an emporium. The emergence of these emporiums, especially in northern parts of Java such as Banten, Cirebon, Demak, and Jepara, resulted in shorter trade distances. This short distance condition encourages the exchange of knowledge, insights, and commodities in the port city area. The period of development of port ports into emporiums was the beginning of the commercial period in Southeast Asia (Reid, 1992).

The development of the port city emporium in the northern region of Java was influenced by the emergence of the Malacca kingdom in the 15th century, which succeeded in dominating the Malacca Strait trade beyond Pasai rule. However, in 1511, the Portuguese succeeded in conquering Malacca and acquiring the Malacca region as their monopoly area and implementing an expensive taxation system. This prompted traders from China, Arabia, Goa, Gujarat, and Europe to avoid Malacca as a stopover and headed straight for the northern port of Java. This political situation led to the emergence of a large port (emporium) in the northern kingdoms of Java (Pribadi, 2005).

The emergence of these large ports provoked an increasingly crowded and diverse international trade. The diversity of trading activities lies not only in the origin of traders but also in trading commodities brought from their home countries, such as cloth, ceramics, jewelry, and so on. These sailing and trading activities also have a broad impact not only on an economic perspective but also in influencing the joints of the social and cultural life of the local residents. 
In this study, researchers focused on reading the impact of the maritime spice route on the port of the north coast of Java and narrow down to the trading port city of Jepara. In this paper, researchers make the trading port city of Jepara a research mitigation point in reading the influence of the spice trade route on the development of techniques and decorative patterns of carving art. The study conducts general observation of the Jepara carving and then linked chronologically based on when the foreign culture appeared acculturated with the local culture.

This research focuses on studying the impact of cultural mixing that affects the development of wood carving in Jepara. According to Koentjaraningrat (1992) culture is the whole idea and human work that must be familiarized with learning and the whole of the results of the works. Referring to this opinion, the research was carried out by studying the events that occurred and the impacts caused by those events in the Jepara region. Studying history needs to be done to find out sequentially in order to get a big and comprehensive picture of the origin, belief or religion that exists and the development of the implementation of the decoration on the artifacts. This is also confirmed by the opinion of Merrill (1965) who says that culture is a complex whole which includes knowledge, belief, art, morals, law, and all skills and habits acquired by humans as members of society.

\section{RESEARCH METHODS}

This study uses a historiography method by collecting various data obtained from sources such as books or academic journals that have a relationship with the theme of the discussion with this paper. Next, the critical stage used when analyzing the data concerning the validity of the data itself. After analyzing the data, the next step is to interpret the data by interrelating various events based on primary data and seeing the impact that appears as a form of collateral effect on the application of decorative symbols on artifacts that also affect the form, technique, material, and function. Then as a final step that aims to facilitate the understanding of the research, this paper is written historiographicaly to make this journal possible to present the results of this paper sequentially. 


\section{DISCUSSION}

The port city on the north coast of Java has experienced significant development due to the international spice trade route. Harbor nodes have appeared starting from the western tip of Banten, Cirebon, Demak to Jepara. Located in the North Java region, Jepara has become a node. Not only because of its strategic location but also because of its trading commodity. At that time, Jepara was also included in the north coast area known as a rice barn because of its abundant rice yields.

Demak and Jepara finally separated themselves from Majapahit because Majapahit experienced a setback, which led to its destruction in 1527. The Majapahit Kingdom experienced a setback due to the emergence of frictional political interests, which led to internal conflicts that consumed the Kingdom's attention. This resulted in neglecting supervision of the royal trading system. The decline of Majapahit's glory resulted in the emergence of a grouping or dichotomy of power, which resulted in several regions breaking away from Majapahit rule. After that, Jepara was successfully conquered by Demak and became the territory under Demak's rule.

The decline of Majapahit is indirectly a symbol of decline from Hindu influence. This situation provided an opportunity for Muslim traders to spread Islam around the former Majapahit rulers such as Jepara and Demak (Aisyah, 2016).

At that time, Jepara port had a much larger capacity than Demak port. Jepara was used to be a military port for the Demak Kingdom in daily life. This situation fostered the confidence from foreign traders such as Chinese, Gujarati, Malay, Arabic, Portuguese, English, and Dutch so that Jepara trading activities crowd increased significantly. (Supriyono, 2013). By Jepara, foreign traders were permitted to live in residential areas that had been provided for trading activities. The existence of this settlement led to the introduction of culture, both among foreign traders and natives.

Jepara, since it was in the reign of Majapahit has been famous for its wood carving skills. This activity has become part of the life of the people of Jepara. The carving activity has been known since the 7th century and began to develop since the reign of Queen Kalinyamat in 1549 (Marizar et al, 2020). During the reign of Majapahit, the carving style was affected by Hindu values. However, since the decline of Majapahit, the influence of the Islamic style began to dominate the Jepara carving style due to the inclusion of Islamic religious values, which start to fuse and turn Jepara into an Islamic kingdom that 
was previously Hindu. (Fajarwati etal, 2020). The reputation of the port of the Kingdom of Jepara also plays a role in the progress of cultural adaptation and acculturation shown in the techniques and styles of Jepara carving. The arrival of other foreign traders such as China, Gujarat, and Europeans also enriched the style and nuances of Jepara carving.

Jepara carving cannot be separated from the influence of Hinduism and become the historical background of Jepara. It can be said that the motif or style of Hindu carving has become the foundation that continues to be applied to the Jepara carving style. For instance, the motifs applied to Jepara wood carvings also appear on the carving illustrations in temples during the heyday of Hinduism (Gustami, 2000). Objects or motifs that often appear in Hindu carving styles include dragons, peacocks, elephants, vines, and natural elements such as mountains. The following are illustrations of some examples of wood carving motifs or styles during the Hindu period.

The peacock is a symbolic embodiment of a holy and graceful creature. According to Hindu belief, the peacock is believed to be the vehicle of the God of War, namely Skanda or Karteya, the son of Lord Shiva. There is also an opinion that the peacock is also a symbol of the upper world, which symbolizes purity and happiness.

In Figure 1, a stylized or simplified form of a peacock motif does not display realistic features. Then in terms of cultivation, the field is filled with decorative ornaments so that there are no empty areas. Unlike the dragon motif that emerged from Javanese culture and was adopted when Hinduism entered, the dragon is a mythological creature that is present in the realm of the human imagination and is mythologized as an underworld creature with the form of a giant, crowned snake that is believed to function as guardians of the waters. In contrast to Chinese culture, dragons are depicted as having legs and without wearing a crown. 


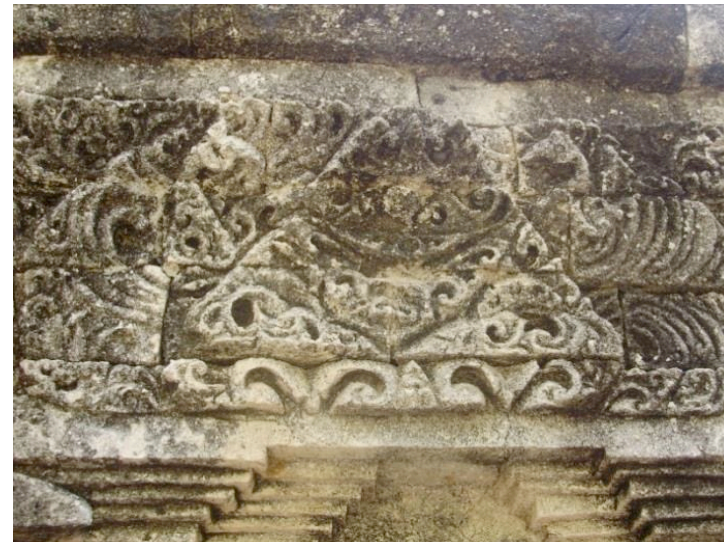

Figure 1: The peacock motif on the tomb of Sunan Sendang is a symbol of sacred creatures in Hinduism Source: Iswati, 2016

In general, the characters of the Hindu carving style, among others, are more decorative and ornamental in nature to create a replete crafted carving area without leaving any space. The objects displayed also tend to be unrealistic and more symbolic (Iswati, 2016).

Dragon, which represents the Hindu era in Jepara, does not display a realist side. The dragon is being depicted full of decorative elements such as scales, which are stylized into plant tendrils. The differences in the application function in a constructive manner between pictures 2 and 3, among others, in Figure 2 , the dragon motif is passive because it is only decorative, while in figure 3 , the dragon motif is active. Emphasizing the decoration side, the dragon motif in figure 3 also has a function that can be classified active decoration. This also roughly shows that dragon motifs are often used not only as decoration but also as a construction function. This is benefited by the gesture and shape of a dragon that allows it to function as a construction. 


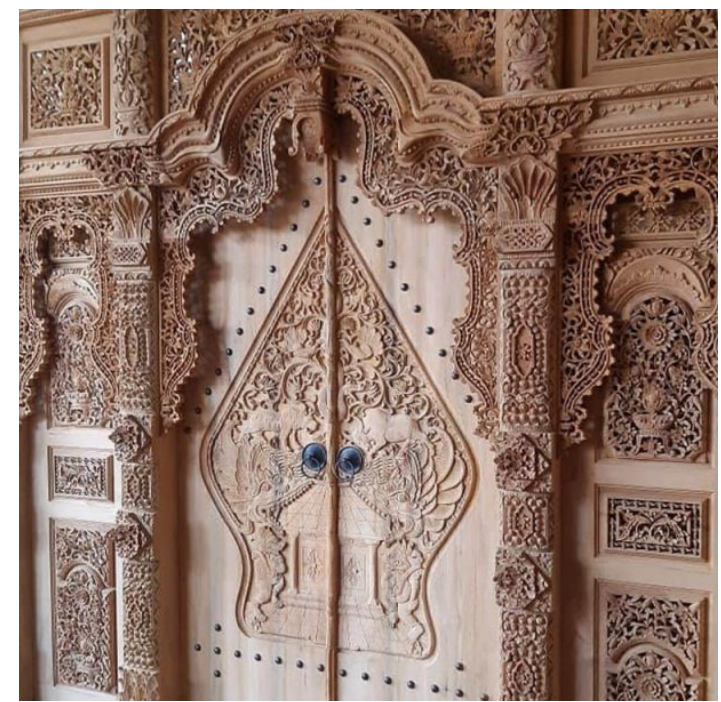

Figure 2. Mountains and dragons motifs with a crown

Source: https://okejohn.com/gebyok-ukir-cantik-asli-jepara-ukuran-3-meter-ciamik/

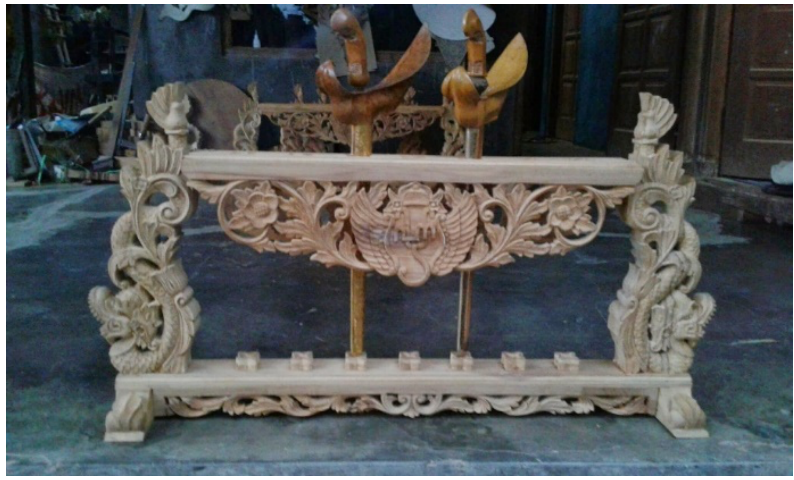

Figure 3. Tendril and dragon motifs with a crown on a wooden keris rack Source: http://gubukseniukir.blogspot.com/2015/05/jagrak-keris.html

The second culture acculturated with the local culture of Jepara is Chinese. Chinese culture is one of the earliest foreign cultures that entered the archipelago. Chinese culture spread because it was driven by the emergence of internal pressures in China. The peak of Chinese migration occurred during the reign of the Ming dynasty from 1368-1644 AD (Hidayat,1993).

Large-scale migration of the Chinese population occurred due to the increasing population in China, resulting in getting hard to get jobs during the Ming Dynasty. This situation affects the emergence of the desire to migrate to improve economic conditions. In addition, it also supported by the opening of international trade routes to Southeast Asia as a result of the war victory by Ching's troops in the Formosa archipelago (Carey, 2008). 
In the era of the Jepara kingdom, the entry of Chinese influence started from the trade route, and since foreign traders were allowed to settle around the trading port. There are few data that show evidence to reveals facts the influence of China culture on the carving artifacts in Jepara. The facts that have been discussed most in the history of Jepara carving include the presence of Cie Gwe Gwan, who was known as a carpenter and carving expert in the 16th century who came from the land of Champa as well as the adopted father of Sultan Haldirin, the husband of Queen Kalinyamat (Pratiwia et al, 2018).

The influence of Chinese on the Jepara carving style can be seen clearly in the historical artifacts during the reign of Queen Kalinyamat in 1549, such as; traces of motifs on the gates of the tomb complex of Ratu Kalinyamat and Sultan Haldirin. In addition, the influence of the Chinese carving style also appears in the artifacts of the Mantingan mosque building.

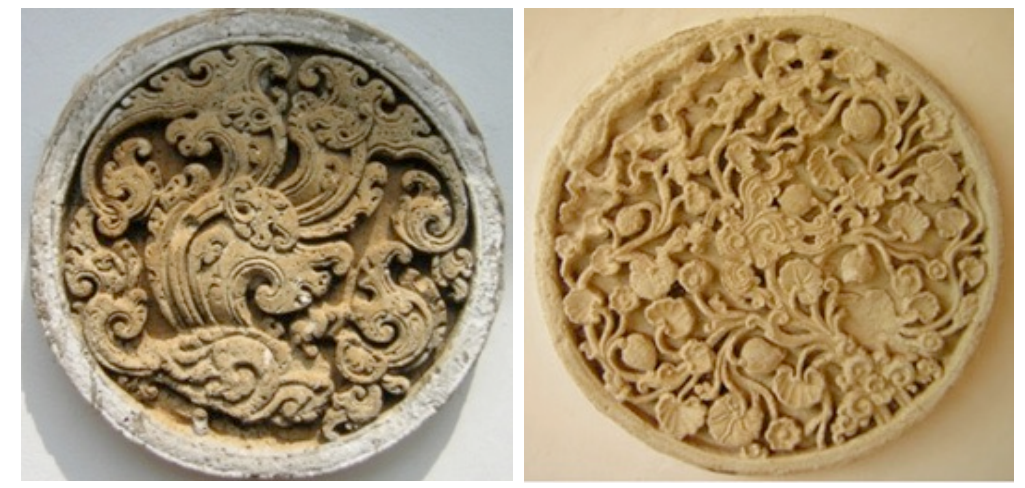

Figure 4. Stylized motifs of a phoenix (left) and a lotus (right) with a circle frame Source: Bagus et al, 2019

One of the traces of evidence of Jepara carving motifs influenced by Chinese arts is the emergence of phoenix motifs, circle-shaped frame combined with local motifs in the form of motifs of coconut, bamboo, pandanus, frangipani, palms, and other vines. A circle-shaped frame (medallion) represents the beginning of life which is interpreted as a symbol of greatness and power. In addition, the circleshaped frame also represents the sun, which is believed to be the source of all life on earth. The circle is also defined as the human life cycle, which reflects the rhythm of life from the beginning of birth and the end of life (Bagus et al, 2019).

While the phoenix motif itself is interpreted as an immortal mythological creature as a symbol of the attainment of human life, which becomes an eternal track record even after death picks it up. In Chinese 
culture, the phoenix is also considered a symbol of resurrection, immortality, and a symbol of reincarnation or rebirth.

Lotus flower motifs are also often found in Jepara carving artifacts influenced by Chinese culture. According to Chinese culture, the lotus flower is a symbol of science and represents spiritual power. The lotus flower also illustrates the hope of life so that it does not fall into the empty worldly values (Bagus et al, 2019).

Meanwhile, the entry of Islamic influence to Jepara began in 1527, after the Majapahit kingdom experienced a decline due to the emergence of internal conflicts that caused division. Some parts of Majapahit start to separate one by one, such as Demak and Jepara. This situation made it easy for Islam to enter and accepted, which became the first Islamic kingdom in the archipelago. Islam entered Jepara through trade routes that began with the entry of traders from Gujarat and Arabia. At that time, Queen Kalinyamat as the ruler of the Kingdom of Jepara provided a place to live for foreign traders while waiting for the repair of her ship to be completed or preparing supplies.

The emergence of these foreign merchant settlements indirectly allowed the introduction of the culture of each merchant with the residents of Jepara. This condition is the gateway to the entry of several cultures and mixing with local cultures. Islam entered Jepara by not getting rid of the old culture but embracing it so that it can be accepted and acculturated with existing local cultural values.

In the discussion of Jepara carving, several carving motifs emerge, which are influenced by approaches and comprehension in Islam. One of them is in Islamic belief to avoid objects related to the literal depiction of living things. This condition made the sculptors in Jepara who had embraced Islam depict living things by disguising the original forms of animals or humans by processing ornamental and decorative shapes.

The images below depict animal figures of animals that are still influenced by Hindu elements such as horses and peacocks. However, since the adoption of Islamic influence, the animal forms have been disguised as ornamental forms. The style of carving that developed under the influence of Islam is known as memet which is defined as a style of carving that does not describe living things such as animals and humans clearly and tangibly (Pratiwia et al, 2018). 


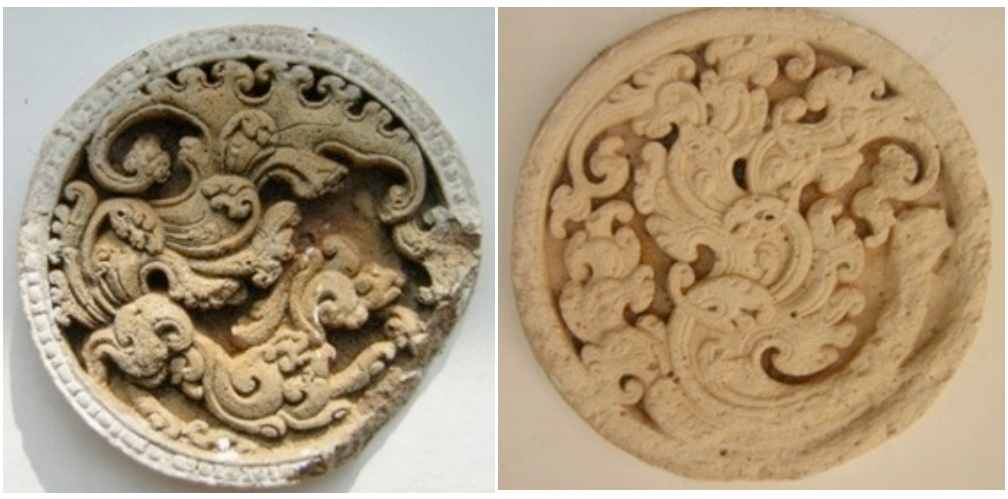

Figure 5. Horse stilation motif (left) and peacocku (right) Source: Bagus et al, 2019

Apart from living things, the motifs of carving that emerged under the influence of Islam were the abstract approach with continuous geometrical compositions and the processing of the form of the holy verses in particular shapes. Some of the artifacts of Jepara carving, which are influenced by Islam still maintain the medal form, which is the influence of Chinese art and culture.

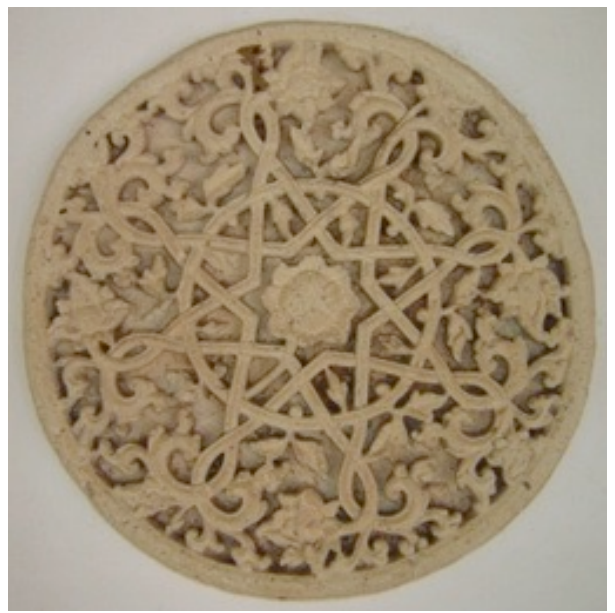

Figure 6. A braided geometric pattern Source: Bagus et al, 2019

The depiction of acculturation at the time of Islam is seen in the interwoven motif in figure 6 . When viewed in detail, the lotus flower motif placed in the center of the ornament, which is the motif used since the entry of Chinese influence in Jepara. Likewise, the flower tendrils on the edges of the frame are the motifs used during the Hindu period and combined with symmetrical geometric motifs as a characteristic of Islamic motifs, known as arabesque motifs.

As the trading port of the Jepara kingdom developed, more and more foreign traders came to trade or only stop by to repair ships and collect supplies to continue their journey. Jepara Port is known to be 
large and safe because apart from functioning as a trading port, Jepara port was a military port for the Kingdom of Demak when Jepara was still under Demak's rule.

Apart from its strategic position and security, the big name of the Jepara trading port is influenced by the existence of the spice trade route. This trade route brought traders from Europe to come to the archipelago and stop in Jepara. Before the European visit to Jepara, the Jepara carving style was only used as a decorative element and did not have a specific function yet. The entry of the Europeans brought a new color to Jepara carving, apart from adding a repertoire of styling, Europeans also brought the value of a function. Especially the function of furniture with the Jepara carving application acculturated with European design styles at that time such as Rococo, Renaissance, Baroque, and Regence.

The Europeans who first stopped in the archipelago were the Portuguese. Many Portuguese missionaries came with a mission to spread Christianity in the archipelago. These missionaries merged with the community and contributed to enriching the insights of the Jepara carvers by introducing the Renaissance carving style that was developing in mainland Europe. The characteristic of Jepara carving from this missionary intervention is the use of lathe techniques and the application of threads which are usually applied to constructive functions such as table legs or chairs. As for the decoration, it usually uses plant, fruit, and animal motifs (Kurniawan, 2008).
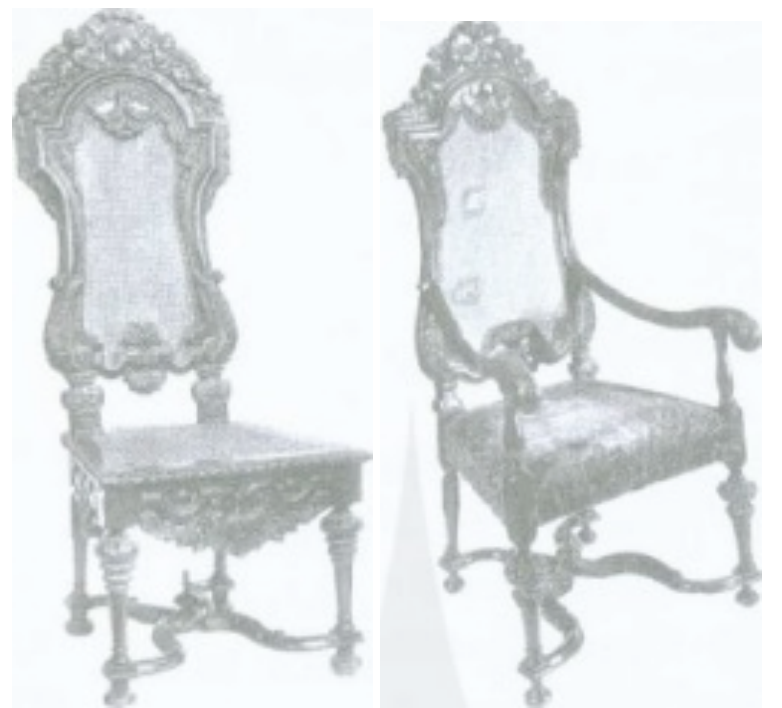

Figure 7. Portuguese style wood carving furniture with floral motifs and lathes on the legs of the chairs Source: Monique van de geijn, et al. (2002). 
Meanwhile, the British also visit Jepara and introduced the Regence style with a lighter and simpler form as a form of transition from the Rococo and Baroque styles during the heyday of Louis XV from France (Kurniawan, 2008).

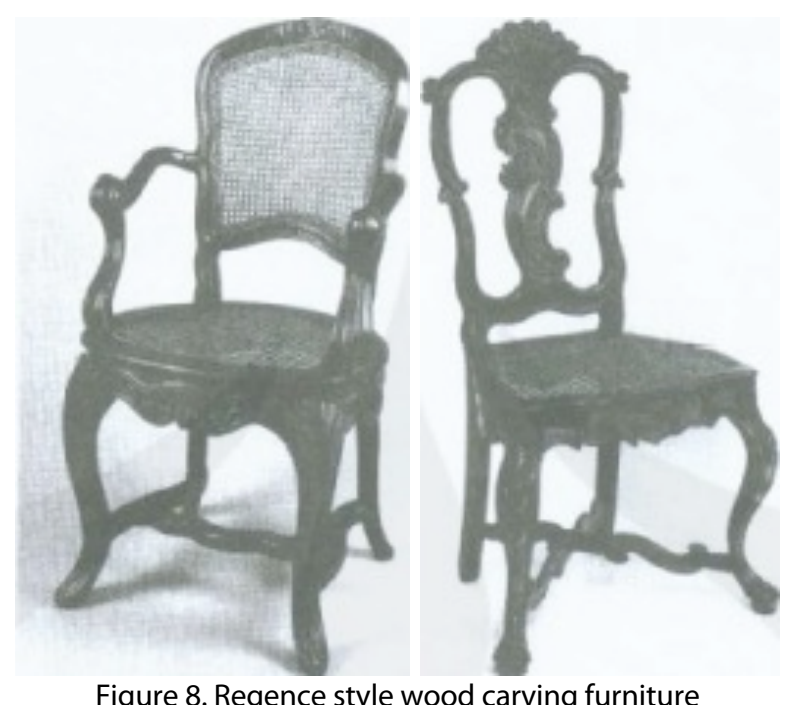

Figure 8. Regence style wood carving furniture Source: Monique van de geijn, et al. (2002).

After that came the Dutch who had a significant impact on the development of carving in Jepara. The arrival of the Dutch in Jepara introduced European carving styles in Jepara. At that time, the Dutch brought the Baroque and Rococo styles as styles that were emerging and being adopted in parts of Western Europe by accentuating a more realistic and solid form. To meet the demands of the European market at that time, the Netherlands established many workshops by bringing in hand carving experts from the Netherlands to collaborate with local Jepara artisans.

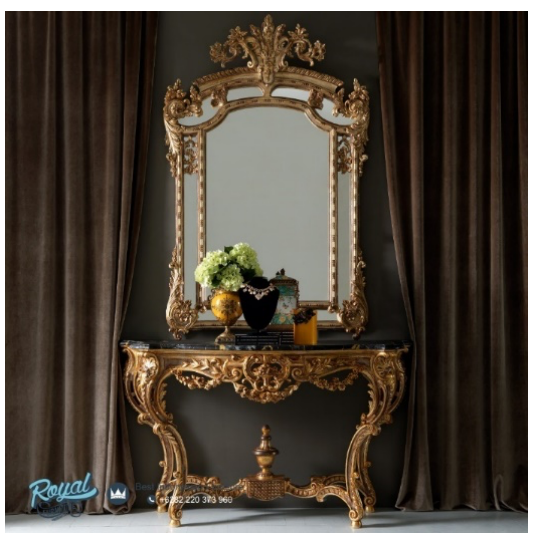

Figure 9. Baroque and rococo style wood carving furniture Source: http;//royalfurniture.co.id 
The Baroque style is an art style that emerged in the 16th century as a form of admiration for the classical church style in Rome. The Baroque style was widely applied to the art and architecture world at that time. The Baroque style itself plays a lot with massive and solid forms with the reflection of ancient natural images that are applied to the use of the acanthus leaf motif. Meanwhile, the Rococo style emerged in the 17th century by accentuating carvings that were organic, twisted, and asymmetrical (Sumarno et al, 2018).

As a result, Jepara carving art has a rich and unique diversity which makes Jepara famous for its carving abilities. The following is a table that shows how these cultures, religions, insights, and techniques are integrated into the journey of Jepara carving in general. 
Table 1. The connection patterns that emerge in Jepara wood carving as the maritime route impact

\begin{tabular}{|c|c|c|c|c|c|}
\hline Pattern & Era & Origin & Marks & Acculturation & Function \\
\hline & $\begin{array}{c}\text { 6th } \\
\text { centuries }\end{array}$ & Hinduism & $\begin{array}{l}\text { Clear shape, clear } \\
\text { objek but not realistic } \\
\text { with peacock bird, java } \\
\text { dragon, elephant, and } \\
\text { flower tendrils full } \\
\text { decoration as religion } \\
\text { symbolic }\end{array}$ & $\begin{array}{l}\text { The combination of existing } \\
\text { Javanese beliefs (animism) } \\
\text { with Hinduism with the } \\
\text { emergence of natural } \\
\text { objects, symbols, and } \\
\text { decoration. }\end{array}$ & $\begin{array}{l}\text { Decorative } \\
\text { Aesthetic } \\
\text { Element }\end{array}$ \\
\hline & $\begin{array}{l}\text { 14th } \\
\text { centuries }\end{array}$ & Chinese & $\begin{array}{l}\text { Medallion shape, } \\
\text { nature object such as } \\
\text { flower tendrils with } \\
\text { phoenix, dragon, horse } \\
\text { lotus flowers }\end{array}$ & $\begin{array}{l}\text { Maintain plant motifs such } \\
\text { as lotus and tendrils as well } \\
\text { as the use of animal } \\
\text { symbols that are still related } \\
\text { to Javanese Hindu beliefs } \\
\text { but with the application of a } \\
\text { medal form in the form of a } \\
\text { circle frame }\end{array}$ & $\begin{array}{l}\text { Decorative } \\
\text { Aesthetic } \\
\text { Element }\end{array}$ \\
\hline & $\begin{array}{l}\text { 15th } \\
\text { centuries }\end{array}$ & Islam & $\begin{array}{l}\text { Stylization of nature } \\
\text { object such as flower } \\
\text { tendrils with horse } \\
\text { lotus flower peacock } \\
\text { and arabesque } \\
\text { geometric }\end{array}$ & $\begin{array}{l}\text { Keeps the medallion shape, } \\
\text { animals like birds and vines } \\
\text { stylized combined with the } \\
\text { arabesque style of } \\
\text { geometric decorations. }\end{array}$ & $\begin{array}{l}\text { Decorative } \\
\text { Aesthetic } \\
\text { Element }\end{array}$ \\
\hline & $\begin{array}{l}14 \text { th- } \\
16 \text { th } \\
\text { centuries }\end{array}$ & $\begin{array}{l}\text { West } \\
\text { European- } \\
\text { Portuguese }\end{array}$ & $\begin{array}{l}\text { Renaissance style with } \\
\text { florals, fruits and } \\
\text { animal objects with } \\
\text { combining lathe and } \\
\text { thread technique } \\
\text { usually as furniture } \\
\text { legs or structure }\end{array}$ & $\begin{array}{l}\text { Using a trendy Renaissance } \\
\text { style that coincidentally } \\
\text { intersects with local carved } \\
\text { objects and decorations } \\
\text { enriched with lathe and } \\
\text { thread techniques }\end{array}$ & $\begin{array}{l}\text { Decorative } \\
\text { Aesthetic } \\
\text { and } \\
\text { Functional } \\
\text { Furniture }\end{array}$ \\
\hline & $\begin{array}{l}16 \text { th- } \\
19 \text { th } \\
\text { centuries }\end{array}$ & $\begin{array}{l}\text { West } \\
\text { European- } \\
\text { Netherlands }\end{array}$ & $\begin{array}{l}\text { The Baroque form with } \\
\text { massive shape with } \\
\text { natural depicted in the } \\
\text { use of the acanthus } \\
\text { leaf motif. the Rococo } \\
\text { style highlighting } \\
\text { organic, curved, and } \\
\text { asymmetrical carvings. }\end{array}$ & $\begin{array}{l}\text { Approaching the Baroque } \\
\text { and Rococo styles, which } \\
\text { are still close to local } \\
\text { carving styles but a realist } \\
\text { and natural by emphasizing } \\
\text { the combination of } \\
\text { materials }\end{array}$ & $\begin{array}{l}\text { Decorative } \\
\text { Aesthetic } \\
\text { and } \\
\text { Functional } \\
\text { Furniture }\end{array}$ \\
\hline & $\begin{array}{l}\text { 16th } \\
\text { centuries }\end{array}$ & $\begin{array}{l}\text { West } \\
\text { European- } \\
\text { British }\end{array}$ & $\begin{array}{l}\text { Introducing the } \\
\text { Regence style with a } \\
\text { lighter form as a } \\
\text { transitional form of } \\
\text { Baroque styles during } \\
\text { the heyday of Louis XV } \\
\text { from France }\end{array}$ & $\begin{array}{l}\text { Introducing a simplified and } \\
\text { lighter style of furniture } \\
\text { (Regence) compared to the } \\
\text { Baroque and Rococo styles } \\
\text { but still using plant vine } \\
\text { carving patterns and curving } \\
\text { shapes }\end{array}$ & $\begin{array}{l}\text { Decorative } \\
\text { Aesthetic } \\
\text { and } \\
\text { Functional } \\
\text { Furniture }\end{array}$ \\
\hline
\end{tabular}




\section{CONCLUSION}

Based on the previous explanation, the world spice trade route has affected areas around the shipping course, including the archipelago. The creation of the maritime spice routes has affected various fields such as politics, trades, religion, and cultures blend with local cultures. As a kingdom that emerged due to its strategic location on the spice route, Jepara has developed rapidly and had wide cultural impact.

Jepara, which already has a strong background in carving since the Hindu era (Majapahit kingdom), has become increasingly developed by various cultures and religions brought by traders from abroad. The acculturation of the exchange and blend cultures, insights, and expertise from various sources played a role in the progress and growth of the art of carving in the Jepara.

\section{REFERENCES}

Bagus, Fivin., et al. (2019). Bentuk Rupa dan Makna Simbolik Motif Ukir Pada Masjid Mantingan Jepara Dalam Konteks Sosial Budaya. Jurnal Imajinasi Vol. XIII. No. 2. (Juli 2019).

Carey, Peter. (2008). Orang Cina, Bandar Tol, Candu dan Perang Jawa: Perubahan Persepsi tentang Cina 1755-1825. Jakarta: Komunitas Bambu

Fajarwati, A. A. S., et all. (2020). Intersection cultural value, nationalism, and commodification behind the Garuda chair as Jepara's signature industries. Humaniora, 11(1), p 29-34.

Gustami, S. (2000). Seni Kerajinan Furniture Ukir Jepara, Kajian Estetik Melalui Pendekatan Multidisiplin. Yogyakarta, DIY, Yogyakarta: Penerbit Kanasius.

Hidayat, Z. M. (1993). Masyarakat dan Kebudayaan Cina di Indonesia. Bandung: Tarsito

Iswati. (2016). Kajian Estetik dan Makna Simbolik Ornamen di Komplek Makam Sunan Desa Sendangduwur Paciran Lamongan. Arty Vol. 5 No. 1. (Januari 2016).

Koentjaraningrat. (1992). Kebudayaan, Mentalitas dan Pembangunan. Jakarta: Gramedia Pustaka Utama Koestoro, L. R. (1996). Prasejarah Sarana Transportasi Air Nusantara. Kongres Prasejarah Indonesia I. Yogyakarta: Assosiasi Prehistori Indonesia.

Kurniawan, Bambang K. (2008). Pengaruh Dominasi Gaya Eropa Pada Mebel Ukir Jepara. Dimensi Vol. 6. No. 1. (September 2008).

Marizar, Eddy., et al. (2020). Development of wood carving furniture technology in Jepara. IOP Conference Series: Materials Science and Engineering. 852. 012146. 10.1088/1757-899X/852/1/012146. 
Merrill, Francis E. (1965). Society and culture: an introduction to sociology. New Jersey: Prentice Hall: p 129 Monique Van de Geijn, et al. (2002). Domestic Interiors at the Cape and Batavia 1602-1795. Den Haag; Waanders Publishers, Zwolle.

Muhajirin. (2018). Aesthethic Expressions of Jepara Carving in Efforts to Deal with The Market Demands. CORAK Jurnal Seni Kriya Vol. 8 No.1. (Mei-Oktober 2018).

Poelinggomang, E. L. (2001). Perdagangan Maritim Indonesia Jaringan dan Komoditinya. Diskusi Ilmiah Arkeologi XII. Makassar: Ikatan Ahli Arkeologi Indoenesia.

Pribadi, Yanwar. (2005). Era Niaga di Nusantara Pada Masa Kerajaan +1500-1700 M. Al Qalam Vol. 22 No. 1. $p$ 65-84. ISSN 2620-598X

Pratiwia, A.P., et al. (2018). Analisa Perkembangan Motif Ukiran Di Jepara Pada Abad Ke-16 Hingga Abad Ke-17. Jakarta: Interior Design Departmen. School of Design. Bina Nusantara University.

Reid, Anthony. (1992). Asia Tenggara dalam Kurun Niaga 1450-1680 Jilid I:Tanah di bawah Angin. Jakarta; Yayasan Obor. p 43.

Sumarno, Carolline., et al. (2018). Gaya Desain Baroque dan Rococo pada Lemari Schepenkast di Museum Sejarah Jakarta. Jakarta: Fakultas Seni Rupa dan Desain. Universitas Tarumanegara

Supriyono, A. (2013). Tinjauan Historis Jepara Sebagai Kerajaan Maritim dan Kota Pelabuhan. Paramita Vol 23, No. 1 (Januari 2013): p 27-39.

Syafiera, Aisyah. (2016). Perdagangan di Nusantara Abad ke 16. Avatara Vol. 4, No.3 (Oktober 2016):p 721 735.

Tjandrasasmita, Uka. (1987). Banten sebagai Pusat Kekuasaan dan Niaga Antar Bangsa, Kumpulan Makalah Diskusi, Banten Kota Pelabuhan Jalan Sutra. Jakarta: Depdikbud, RI.

Wibisono, Sonny Chr. (2004). A Brief History of Research on Trading Ports/Harbour Sites. Country Report Indonesia dalam Workshop on the Archaeology of Early Harbours and Evidence for Inter-Regional Trade. Singapore: ARI-NUS 